\title{
Effectiveness of Pontianak City Government Innovation Policy Bisnis Cakep Lalu Lintas Lancar and Government and Smart City Landmark
}

\author{
${ }^{1}$ Akhi Ulqadri, ${ }^{2}$ Verdico Arief \\ ${ }^{12}$ D-IV Public Administration Study Programme \\ Pontianak State Polytechnic \\ Email: ${ }^{1}$ akhiulqadri@gmail.com, ${ }^{2}$ verdico.arief@gmail.com
}

\begin{abstract}
Pontianak is one of the regions that get appreciation from the Government of the Republic Indonesia on various creation innovation program policy in public administration sector. Among the products in the field of innovation is the application bisnis cakep lalu lintas lancar $(B C L)$ and application government and smart city landmark (Gencil). Both applications are used Pontianak City Government to manage the government and public service. All policies or programs implemented by the government must be effective. However, to produce a product effectiveness of a policy or program should do some research. For that we need research that focuses in measuring about how effectiveness of Pontianak City government innovation policy bisnis cakep lalu lintas lancar and government and smart city landmark. This research is conducted qualitatively with the aim to find and search data and information in depth related to how big the effectiveness of product created. Thus will be known how the level of effectiveness of a policy or program that has been implemented by the government of Pontianak City.
\end{abstract}

Keywords: Effectiveness; Innovation; Pontianak

Link DOI : http://dx.doi.org/10.31314/pjia.7.2.108-122.2018

Copyright (C) 2018, Publik : (Jurnal Ilmu Administrasi), ISSN: 2301-573X (Print), ISSN: 25812084 (Online) 


\section{INTRODUCTION}

Bisnis Cakep Lalu Lintas Lancar or known as a BCL and goverment and smart city landmark or more known as a Gencil that are two innovation product of public service owned by Pontianak City Government. Both of the product have two advantage each of them, bisnis cakep lalu lintas lancar's product (BCL) it went into top 40 product innovation of public service in Indonesia. While the existence of Gencil has get appreciation from Presiden of Indonesian Republic Joko Widodo and appeal to the other local government to make this product as a prototype. With the product of public service innovation was hoped that it will makes Pontianak City Government easier giving service to the local citizen.

Both of the product have implemented by Pontianak City Government more than two years ago. During the implementation, it involves regional device organization. The aim of this public service innovation is to minimize the cooporation among regional device organization. Based on that thing, it is interesting to know how effective the implementation of Bisnis Cakep Lalu Lintas Lancar inovation product (BCL) and government and smart city landmark (Gencil) is owned by Pontianak City Government.

Effectiveness is the utilization of resources, facilities and infrastructure in a certain amount that is consciously set beforehand to produce a number of goods for service carried out. Siagian (2007:24). Effectiveness (outcome) is the relationship between the output and the goals or objectives that must be achieved. Mashun (2006:182). Richard M Steers stated that there are several factors that influences effectiveness including:

(1) organizational Characteristics,

(2) environmental Characteristics,

(3) characterictics of workers,

(4) management policies and practices. Sterss (1985:9).

\section{RESEARCH METHOD}

Research of effectiveness of Pontianak City Government innovation policy bisnis cakep lalu lintas lancar and government and smart city landmark is a qualitative research. Qualitative research is a research aimed at describing and analyzing phenomena, events, social activities, attitudes, beliefs, perceptions, thoughts of individuals or groups. Sukmadinata (2010). To get the data that needed to make the research, the researcher uses observation study, interview, and documentation. Determination of the informans uses by purposive and snowboal. According to Sugiono qualitative research method is a research method based on the philosophyof postpositivism, used to examine the condition of natural objects, (as opposed to experimentation) where the researcher is a key instrument, data source sampling is done by purposively and Snowboal, collecting techniques with triangulation (combined), data analysis is inductive/qualitative, and research results emphasize the meaning rather than 
generalization. Sugiyono (2016). After the data is obtained that will be analyzed using analysis data concept that said by Miles and Huberman which includes data collection activities, data presentation, data reduction, and conclusions. Miles and Huberman (1992).

\section{RESULT AND DISCUSSION}

Characteristics organization consist of structure and technology. In this case what is mean by structure is relationship that are relatively fixed in nature as found in organizations, it related to the composition of human resources. Meanwhile, what is mean of technology is the mechanism of an organization to convert raw inputs into finished outputs. Technology can have various forms, including variations in mechanical processes used in production, variation in materials used and variations in technical knowledge used to support activities towards the goal (Steers 1985 9-10).

Bisnis cakep lalu lintas lancar (BCL) and government and smart city landmark (Gencil) is a innovation product of public service made by Pontianak City Government. In the beginning of the appreance in about 2016 this product innovation is managed by regional device organization transportation communication and informatic Deparment of Pontianak City. However, with the development of the government organization in Pontianak city, the depertment of transportation communication and information of Pontianak city was split into two different regional device organizations, including the Pontianak city transportation department and the communication and informatics department, each of them has a mandatory authority and tasks and their repective functions, including in the management of innovation products in the public service field of the Transportation Office of Pontianak City were given the rights and authority to manage bisnis cakep lalu lintas lancar (BCL), and meanwhile the deparment of communicatin and informatics was given the rights and authority to manage government and smart city landmark (Gencil) by Pontianak City Government. This is stated in the Pontianak Mayor Decree number 124/ORG/2018.In management bisnis cakep lalu lintas lancar (BCL) Transportatin Department of Pontianak City was given authority to manage it. In the implementation, Transportation Department of Pontianak City make a cooporation with the outside of regional device organization of Pontianak City such as Police and Army. The role of the two organization is to keep safety and discipline during the bisnis cakep lalu lintas lancar (BCL) implemented.

Meanwhile,Communication and Informatics Department in management of government and smart city landmark (Gencil) cooporate with a community organization who care with the development of information technology and communication in Pontianak. This community name them as Pontianak Digital Stream. The legality self 
application is made by PT. Dua Agung, which is part of the Pontianak Digital Stream Community. Then the application is managed together with Communication and Informatics Department of Pontianak City. Pontianak City Government in this case provides the authority to Communication and Informatics Department to be creative in developing and managing the application using variety of ways. In developing of government and smart city landmark's application (Gencil), Communication and Informatics Department choose to use public private partnership. This is chosen in order to make the development can be carried out effectively and efficiently.

Bisnis cakep lalu lintas lancar (BCL) and government and smart city landmark (Gencil) are made by utilizing various kind of modern technology in his era to make Pontianak City Goverment easier to carry out public service activities. Utilization of this technology must absolutely be done by the Pontianak City Goverment in order to balance the demands of the work, the paradigm of the progress of the era, and also the wishes of the community. With the using of technology, it will make the work mandated by Pontianak City Government to the Transportation Department and Communication and Informatics Department be carried out more effectively and produce efficient value. Creating an innovation product in the field of public services is a neccessity for the current local government. The public service provided by local government must be in line with technological developments in the scope of society. This is a way to create good and righ governance arrangements.

What done by Pontianak City Government is in line with what Sabbarudin has said. The government must continue to strive providing good, responsive and innovative services in answering the need and desires of the citizen. Perceptions that have tended to regard society as paasive consumers must be abandoned. Citizen must be seen as parties who have a role as well as government partners in the administration of government and public services. Sabaruddin (2015)

\section{Effetiveness in terms of Environments}

The success of a policy or program sometimes cannot be separated from enviromental factors. Effectively of everything cannot be separated from the environmental factors that influence or are around it. The environment includes two aspects which are somehow different but interconneced. First is the external environment, which is all the forces that arise outside organizational boundaries and influence decisions and actions within the organization. Second is the internal environment, this enviroment is generally known as the organizational climate, including various work environment attributes. Steers (1985).

Including bisnis cakep lalu lintas lancar (BCL) and government and smart city landmark (Gencil) can be said effective if the environment is which 
these policies, program or products are created and implemented can support. To see how the enviroment supports the business presence of bisnis cakep lalu lintas lancar (BCL) and government and smart city landmark (Gencil) can be started by looking at the enviromental conditions of the government climate.

Pontianak is the capital city of West Borneo Province. The area of Pontianak city is approximately 107.82 $\mathrm{km} 2$ and inhabited by approximately 664,394 inhabitants that the majority of whom are nominated by Malay, Dayak, and Chinese tribes. The social life of the people in Pontianak City now can be said to be peaceful. It is very different compared to the early 2000s, where conflict between tribal civel wars had occurred in this area. The peace and tranquility of people's life in Pontianak Cityis inseparable from the interference of the government to manage the governance system well and correctly.

One thing to be proud of Pontianak City that the city has the title as one of the cities with the best level of electronic government development in Indonesia. In 2017, Pontianak was crowned by the Indonesia Republic State Administration Institute as one of the cities with the best number of open data in Indonesia. In addition, Pontianak has been named as an innovation laboratory in the field of public services, and has become a role model or reference for other local governments in the developments of various kinds of innovations in the field of public services, especially in field related to electronic government. Until 2018, the Pontianak City government already has 153 innovative products in the field of public services that majority using electronic government concepts. Among the hundred of innovation are bisnis cakep lalu lintas lancar (BCL) and government and smart city landmark (Gencil).

Implementation of bisnis cakep lalu lintas lancar (BCL) and government and smart city landmark or Gencil in Pontianak City can be said to be successful. This success is supported by two main factors, that is hard work of Pontianak City Government, and the second that there is participation of the citizen who want to pursue various kind of government innovation in the field of public services implemented by the Pontianak City Government.

Bisnis cakep lalu lintas lancar (BCL) is an innovation in the arrangement of parking area and vehicle traffic in the central business district (CBD) area in Pontianak City. The central business district (CBD) area includes the Tanjungpura road, Agus Salim road, and Diponegoro road in Pontianak City. Previously, before there was a bisnis cakep lalu lintas lancar $(\mathrm{BCL})$ in this area was very trafficejammed. This is caused by a variety of factors, first is the factor of the business area, then the factor of crowded vehicle that park in any place, then the limited of parking area, then the width of the road that can be said too small and it is not proportional to the number of vehicles 
passing on the road. The four factors have caused traffic jams in the central business district (CBD) in Pontianak City. In order to solve these problems, Pontianak City Government gives authority to Transportation Department of Pontianak City looking for the solution of these problems. Coming from that situation then appear an innovation called bisnis cakep lalu lintas lancar (BCL).

Environmental factor that significantly influence the success of implementing bisnis cakep lalu lintas lancar (BCL) include the security environment, economic environment and social environment. The security enviroment is the main factor that must be considered, because if there is no guarantee of security no matter how good things you want to do will not be seccessfully realized. The implementation of bisnis cakep lalu lintas lancar (BCL) is carried out by installing CCTV and loudspeakers at various strategic points in the central business district (CBD) in Pontianak which aims to monitor the area through the command center or control room that available in the Transportation Department of Pontianak City. Moreover, except of installation of CCTV and loudspeakers, Transportation Department of Pontianak City also conducts routine patrols everyday, in which the patrol is devided into threee shifts, first shift carried out on the morning to noon then the second shift is carried out from noon to evening, and the third shift is carried out in the afternoon until night.During the patrol by
Transportation Department of Pontianak City assisted by police and also army. This is done to ensure the safety of patrollers when conducting patrol activities and assist in maintaining the facilities used to implement these activities. Imagine if the activity supporting equipment such as CCTV and loudspeakers installed at various points in the central business district (CBD) was stolen and damaged by irresponsible parties, of course bisnis cakep lalu lintas(BCL) activities would not be held by smoothly until now. With a safe environment, everything that needs to be planned will be able to be carried out properly according to predetermined targets.

Furthermore, except of environmental security that has a very significant effect on the succes of implementing bisnis cakep lalu lintas lancar (BCL) is an economic environment. Economic environment is an environment that is related to buying and selling activities and also the marketing of people who are engaged in activities around the central business district (CBD). Basically everyone who does business activities certainly wants something fast, easy and guaranteed. To get that, we need crative and innovative business. Bisnis cakep lalu lintas lancar (BCL) is present to answer the challenge. Previously, before there were bisnis cakep lalu lintas lancar (BCL) economic activity in the central business district (CBD) of Pontianak City was normal. But it was a little disturbed by the traffic 
irregularities in the central business district (CBD) of Pontianak City. So, it hampers the process of business transactions in the region. However, since the implementation of bisnis cakep lalu lintas lancar (BCL) activities in the economic field in the central business district area (CBD) of Pontianak City has become smoother, thus increasing the turnover of economic activists who are active in the area only that people or consumers in the economic sector become feel more comfortable doing buying and selling transactions in the region.

The success of implementing bisnis cakep lalu lintas lancar (BCL) also cannot be separated from the support of the social environment. There are two social factors which are the main components, which contribute to the success of the implementation of this policy. The first social factors is the obedience of the local community to the presence of business policies for good traffic or (BCL). People want to accept the presence and implementation of this policy. In this case, what is meant by the community are people who are active in the central business district (CBD) in the city of Pontianak, starting from businesses such as shop owners or traders, those who take advantage of opportunities to make money in the central business district (CBD) which includes parking attendants, porters of goods and services, entrepreneurs of transportation services. The second social factor is customers. Customers in this case are people who purchase goods or services around the central business district (CBD) area in Pontianak City. With the presence of good business traffic or (BCL), customers feel more comfortable in carrying out economic activities. Previously, before this policy was implemented, when they wanted to carry out activities in the central business district (CBD) area, there was a sense of boredom that arose from themselves because the atmosphere of the road traffic around the area was jammed, and added irregular parking arrangements made they do not want to waste their time too long in that area. Usually when their main business has been completed, they will immediately leave the area. But now, since the implementation of bisnis cakep lalu lintas lancar (BCL), consumers feel more comfortable doing side activities in the central business district (CBD), such as holding meetings, discussing business or investment prospects and opportunities, socializing, and just fill your spare time by walking down the central business district (CBD) area in Pontianak City.

Environmental factors also influence the success of implementing government and smart city landmark (Gencil) applications. Similar with bisnis cakep lalu lintas lancar (BCL). In implementing government and smart city landmarks (Gencil) there are several environmental factors that significantly influence the success of policy implementation. The first factor is political environmental factors, and the 
second factor is social environmental factors. From the political environment sector, Pontianak City is the Capital of West Kalimantan Province. A Provincial Capital City must be able to provide good examples to other areas around it. This aims to motivate other regions so that they can develop quickly and have equal development with the provincial capital. For this reason, all government and private stakeholders participate in creating government and smart city landmark (Gencil) applications in order to make a change in the concept of public service paradigm and also governance in Pontianak which is different from other regions, which carries the concept of effectiveness and efficiency. From the collaboration in the form of public private partnership, the government and smart city landmark (Gencil) application was born, and until now this application is one of the applications that are considered important by the government and the people of Pontianak in carrying out their daily activities.

This application is one of the leading innovation products owned by the Pontianak City Government. Even this application has received appreciation from the President of Indonesian Republic Joko Widodo and urges other regions in Indonesia to follow the example of what has been done by the Pontianak City Government. With the appreciation of the existence of this government and smart city landmark (Gencil) application, it indirectly raised the rating of the Pontianak City
Government, including the Mayor and Vice Mayor. This has more or less affected the electability of the two political figures in simultaneous regional elections in the province of West Kalimantan. There is or not a direct effect, but certainly the presence of government and smart city landmark (Gencil) application helped them win the regional head election contestation either in the realm of West Kalimantan Governor election or in the realm of Pontianak Mayor elections in 2018.

In addition to the political environmental factors that contributed to the successful implementation of government and smart city landmark (Gencil) applications, social environmental factors also contributed to the successful application of this application. People of Pontianak City are known as people who are very concerned with technological development. Although the location of Pontianak City is relatively far from the center of Indonesia's capital city, Jakarta, but the development of information and communication technology in Pontianak City is quite dynamic. This is inseparable from the strategic position of Pontianak City which is not too far from Malaysia. Plus the many influences of technology from the countries of Malaysia and the People's Republic of China to the City of Pontianak make Pontianak City community in the development of information technology and communication is not inferior to other regions in Java such as Jakarta, Bandung, 
Semarang, Jogjakarta, or Surabaya. Pontianak City's people are accustomed to living side by side with things related to information and communication technology such as smartphones or other gadged. Majority of the Pontianak people have these enthusiasts to support their daily lives. The majority of the Pontianak people also have social networks. Government and smart city landmark (Gencil) applications carry concepts such as social networks, but have a type of government to citizen. This is a means to bring the Pontianak City Government closer to its people. In the application the people/citizen can interact with the government directly, and each interaction will be responded. To make the community feel at home using the government and smart city landmark (Gencil) application, there are various kinds of diverse features, ranging from culinary information, information on important places and strategis, important events, various current news from the local level and national to international, information on food prices, as well as electronic reports of citizen reports where the people can interact with the Pontianak City Government and convey various complaints about the problems that occur around Pontianak City.

People of Pontianak City highly appreciates the existence of government and smart city landmark (Gencil) applications, especially young people. This is proof that the people of Pontianak City supports the Government in implementing government and smart city landmark (Gencil) applications as a means or medium of public service based on information and communication technology that carries the concept of one stop service.

\section{Effectiveness in terms of the Charateristics of Workers}

Workers are human resources who are tasked with carrying out the work assigned to them. Whether or not a job is more or less influenced by the character of the worker. Van Meter and Van Horn said that the attitude of the recipient or the refusal of the implementer would be very dangerous to affect the success or failure of the performance of public policy implementation. This is very possible to occur because the policy implemented is not the result of the formulation of local residents who know the form of the problems and problems they feel. But the policy that will be taken by the implementor is a top down policy that is very possible the decision makers never know (not even able to touch) the needs, desires, or problems that the citizens want. (Agustino, 2016).

Steers also stated about the importance of the workers' role in carrying out the tasks assigned to them. Different workers have different views, goals, needs and abilities. This variation in human nature often causes people's behavior to differ from one another, even though they are placed in the same work environment. Implementation of bisnis cakep lalu lintas lancar (BCL) and government and smart city landmark 
(Gencil) is carried out by parties who are competent in their respective fields. The implementor is chosen based on expertise in their respective fields. It is intended that the business implementation of bisnis cakep lalu lintas lancar (BCL) and government and smart city landmark (Gencil) can be carried out effectively, and produce high efficient value. Thus it will be able to produce a high level of productivity performance from the state apparatus. The following is a list of the division of work portion of business executives in bisnis cakep lalu lintas lancar (BCL) and government and smart city landmark (Gencil).

Tabel 1. Job Description Implementor Bisnis Cakep Lalu Lintas Lancar (BCL)

\begin{tabular}{|c|c|c|}
\hline No & Position & Workload \\
\hline 1 & $\begin{array}{l}\text { Head of Transportation } \\
\text { Department Pontianak City }\end{array}$ & $\begin{array}{l}\text { Person in charge and leading the implementation of } \\
\text { bisnis cakep lalu lintas lancar (BCL). }\end{array}$ \\
\hline 2 & $\begin{array}{l}\text { Head of Road Transportation } \\
\text { Traffic Sub Division } \\
\text { Transportation Department } \\
\text { Pontianak City }\end{array}$ & $\begin{array}{l}\text { The head of bisnis cakep lalu lintas lancar (BCL) is } \\
\text { tasked to control and supervising orderly traffic flow } \\
\text { manually by utilizing the ATCS (Area Traffic Control } \\
\text { System) in the highway traffic control room in the } \\
\text { Central Business District (CBD). }\end{array}$ \\
\hline 3 & $\begin{array}{l}\text { Patrol officer of Transporation } \\
\text { Department Pontianak City }\end{array}$ & $\begin{array}{l}\text { Manually carry out supervision and control of bisnis } \\
\text { cakep lalu lintas lancar (BCL) in the Central Business } \\
\text { District (CBD). }\end{array}$ \\
\hline 4 & $\begin{array}{l}\text { Officerof ATCS (Area Traffic } \\
\text { Control System) } \\
\text { Transportation Department } \\
\text { Pontianak City }\end{array}$ & $\begin{array}{l}\text { Controlling the Central Business District (CBD) area } \\
\text { from the ATCS command center (Area Traffic Control } \\
\text { System) in the highway traffic control room in the } \\
\text { Central Business District (CBD). }\end{array}$ \\
\hline 5 & Police and Army & $\begin{array}{l}\text { Support and companion of Transportation Department } \\
\text { Pontianak City in the implementation of bisnis cakep } \\
\text { lalu lintas lancar (BCL). }\end{array}$ \\
\hline
\end{tabular}

(Sumber: Penelitian 2018)

Copyright (C) 2018, Publik : (Jurnal Ilmu Administrasi), ISSN: 2301-573X (Print), ISSN: 25812084 (Online) 
Tabel 2. Job Description Implementor Government and Smart City Landmark (Gencil)

\begin{tabular}{cll}
\hline No & \multicolumn{1}{c}{ Position } & \multicolumn{1}{c}{ Workload } \\
\hline 1 & Mayor and Vice Mayor & $\begin{array}{l}\text { Person in charge of implementing government and } \\
\text { smart city landmark (Gencil). }\end{array}$ \\
2 & $\begin{array}{l}\text { Head of Communication and } \\
\text { Informatics Department } \\
\text { Pontianak City }\end{array}$ & $\begin{array}{l}\text { Director of the implementation of government and } \\
\text { smart city landmark (Gencil). }\end{array}$ \\
3 & $\begin{array}{l}\text { Head of Electronic Services and } \\
\text { Telematics Division }\end{array}$ & $\begin{array}{l}\text { Chairman of the implementation of government and } \\
\text { smart city landmark (Gencil). }\end{array}$ \\
4 & $\begin{array}{l}\text { Head of Complaint Service } \\
\text { Center Section }\end{array}$ & $\begin{array}{l}\text { Secretary for the implementation of government and } \\
\text { smart city landmark (Gencil). }\end{array}$ \\
5 & $\begin{array}{l}\text { Officer of the Eletronic Services } \\
\text { and Telematics Section }\end{array}$ & $\begin{array}{l}\text { Government and smart city landmark (Gencil) } \\
\text { implementation team }\end{array}$ \\
6 & Pontive Center & $\begin{array}{l}\text { Government and smart city landmark (Gencil) } \\
\text { implementation team }\end{array}$ \\
& & $\begin{array}{l}\text { Programer development maintenance, service aplikasi } \\
\text { government and smart city landmark }\end{array}$
\end{tabular}

(Source: Research 2018)

In the implementation of bisnis cakep lalu lintas lancar (BCL) and government and smart city landmark (Gencil) involve external parties that are not a direct part of the structure of the Pontianak City Government. In addition to implementation, the development also involves external parties that are intertwined in the form of cooperation with the public private partnership system. This is done in order to accelerate the development of the system and can save resources. Every party that deals with the implementation of bisnis cakep lalu lintas lancar (BCL) and government and smart city landmark (Gencil) is always maintained in a climate of co-operation so that it continues to be smoothly and conducive. This is done to create a positive climate among fellow executives. With good communication, it is hoped that it will create a comfortable work atmosphere and thus they can work well and professionally.

\section{Effectiveness in terms of Management Characteristics}

Bisnis cakep lalu lintas lancar (BCL) and government and smart city landmark (Gencil) are innovation products owned by the Pontianak City Government. This product was made to streamline the work of the Pontianak City Government in carrying out public services. Effective or not of a policy, 
program or product implemented by an organization can be seen from the value of efficiency resulting from the using of the technology used. Steers states that managers play a central role in the success of a company through planning, coordinating, and facilitating activities aimed at the target. It is their duty to ensure that the organizational structure is consistent with and beneficial to the existing technology and environment. Steers (1985). In implementing bisnis cakep lalu lintas lancar (BCL) and government and smart city landmark (Gencil) businesses, the implementors within the organization make management always try to utilize the latest technology so that it can produce effectiveness and efficiency in its implementation. Bisnis cakep lalu lintas lancar (BCL) and government and smart city landmark (Gencil) are considered to be able to produce the desired efficiency value so that both products of this policy can be said to be effective.

Tabel 3. Efficiency Value of Bisnis Cakep Lalu Lintas Lancar (BCL).

\begin{tabular}{|c|c|c|}
\hline No & Content & Efficiency Resulted \\
\hline & CCTV & $\begin{array}{l}\text { Replacing human work, it can works online } 24 \text { hours non-stop and has good } \\
\text { and old power, equipment that can be used for a long time and maintenance } \\
\text { of equipment is not too expensive. If there is no CCTV, it must uses human } \\
\text { resources to keep every location point } 24 \text { hours non-stop and will certainly } \\
\text { cost more. }\end{array}$ \\
\hline 2 & Loudspeaker & $\begin{array}{l}\text { It can provide a hostage to the people from a distance, when there is a } \\
\text { violation the officer can immediately reprimand the violator from the CCTV } \\
\text { control room, and do not have to come directly to the crime location. If there } \\
\text { is no loudspeaker, it will make the work of the officer to be difficult, } \\
\text { because every time there is a violation recorded on CCTV, then the officer } \\
\text { must come directly to the location of the incident to reprimand and take } \\
\text { action against the violation that occurred, and it not sure when the officer } \\
\text { came to the location of the offender still at the location of the incident. }\end{array}$ \\
\hline 3 & Patrol Officer & $\begin{array}{l}\text { Doing some work that cannot be fully implemented by CCTV and } \\
\text { loudspeakers. Carry out social and humanism work. Because if there are no } \\
\text { Patrol Officers the functions of CCTV and Loudspeakers will not work } \\
\text { optimally. Humans must be able to utilize technology well so that it can } \\
\text { facilitate all the work in life so that it can produce great efficiency values. }\end{array}$ \\
\hline
\end{tabular}

(Sourse: Resource 2018)

Copyright (C) 2018, Publik : (Jurnal Ilmu Administrasi), ISSN: 2301-573X (Print), ISSN: 25812084 (Online) 
Tabel 4.Government and Smart City Landmark (Gencil) Value of Pontianak City.

\begin{tabular}{|c|c|c|}
\hline No & Content & Efficiency Resulted \\
\hline 1 & Culinary Information & $\begin{array}{l}\text { Providing information that related to various culinary information in } \\
\text { Pontianak City, if there is no content like this, information promotion will be } \\
\text { done manually through print or electronic media, brochures, posters which } \\
\text { certainly cost a lot of money and not sure the information is right on target. }\end{array}$ \\
\hline 2 & Place Information & $\begin{array}{l}\text { Providing information about various important places in the city of } \\
\text { Pontianak, start from government agencies, hospitals, security offices, } \\
\text { tourist attractions, hotels, places of worship and so on. If there is no content } \\
\text { like this, it will make difficult for people who will looking for various types } \\
\text { of places, especially for tourists }\end{array}$ \\
\hline 3 & Event Information & $\begin{array}{l}\text { Providing information on various important events around the Pontianak } \\
\text { City, such as government events or events such as entertainment, seminars, } \\
\text { concerts, exhibitions, religious events and so on. If there is no content like } \\
\text { this, it will be difficult for people who want to find various events in } \\
\text { Pontianak City. Asking manually for each person or tour agent will certainly } \\
\text { take a very long time, and the information obtained is not sure correct and } \\
\text { accurate. }\end{array}$ \\
\hline 4 & News Information & $\begin{array}{l}\text { Providing local, national and international news information in one large } \\
\text { place without any difficulties like manually opening the news search engline } \\
\text { application available on smartphones or other gadged, and also no need to } \\
\text { bother buying print newspapers just to read and find out the latest news. If } \\
\text { there is no content like this, the people will be bothered by having to } \\
\text { manually search for news either through electronic or print media, which } \\
\text { will certainly take a long time. }\end{array}$ \\
\hline 5 & Foods information & $\begin{array}{l}\text { Providing information on the latest and actual food prices that sale around } \\
\text { the Pontianak City to the public so that people know the price of the food } \\
\text { market and avoid being deceived and harmed by unscrupulous food sellers } \\
\text { in traditional markets. In addition, it also provides information to traders to } \\
\text { sell their merchandise without exceeding the stipulated tariffs, and not to sell } \\
\text { below the tariff because it could cause the trader to suffer losses. If there is } \\
\text { no content like this, then more or less it will hurt people and traders because } \\
\text { they do not know the latest food prices on the market. }\end{array}$ \\
\hline 6 & E-Citizen Report & $\begin{array}{l}\text { Helping to bring people closer to the Pontianak City Government and so it } \\
\text { too for the governement become closer to the people. Communities can } \\
\text { report various types of public services that are not appropriate with their } \\
\text { functions, cut down on the bureaucratic and administrative channels that are } \\
\text { convoluted, can participate in helping the Government in managing the } \\
\text { order of public services and governance in order to be better and right. }\end{array}$ \\
\hline
\end{tabular}

(Source: Research 2018).

Copyright (C) 2018, Publik : (Jurnal Ilmu Administrasi), ISSN: 2301-573X (Print), ISSN: 25812084 (Online) 
The using of technology in the implementation of bisnis cakep lalu lintas lancar (BCL) and government and smart city landmark (Gencil) is done to facilitate the work of the government apparatus in managing and fixing their area. The using of this technology can trigger government officials to work more and more actively. Thus it will be able to cut the completion time of a job and increase the value of work productivity.

\section{CLOSING}

\section{Conclusion}

Overall bisnis cakep lalu lintas lancar (BCL) and government and smart city landmark (Gencil) in Pontianak City have been implemented effectively. This can be accomplished by a combination of appropriate utilization and the using of technology and supported by parties who can use the facility properly and correctly. However, there is still a need for additional resources in order to increase the efficiency value of bisnis cakep lalu lintas lancar (BCL) and government and smart city landmark (Gencil), both in terms of technology and employees implementing these activities. In addition, good efforts are also needed to protect and maintain also update the technology assets that have been owned so that the function and usage period can last a long time. Thus the Pontianak City Government can utilize the technology to its full potential as a means of providing services to its citizens. The using of information and communication technology in the world of government that carries electronic government can improve government performance and also guide the government in implementing good and right governance.

\section{REFERENCE}

Agustino, Leo. (2016). Dasar-dasar Kebijakan Publik. Edisi Revisi. Bandung: Alfabreta.

Arief, Verdico. (2007). The Development Effectiveness of Gencil (Government and Smart City Landmark) Android Base Application by Pontianak City Government. Proceedings Simposium Kebudayaan Indonesia Malaysia Bandung: Unpad Press, 137-147.

Indrajit, Richardus Eko. (2016). Electronic Government. Yogyakarta: Preinexus.

Mahsun,Mohamad. (2006). Pengukuran Kinerja Sektor Publik.Yogyakarta: Penerbit BPFE

Miles, Matthew B. dan A. Michael Huberman. (1992). Analisis Data Kualitatif; Buku Sumber tentang Metode-Metode Baru. Terjemahan Tjetjep Rodendi Rohidi. Jakarta: Universitas Indonesia Press.

Nugroho, Rian. (2017). Public Policy.

Edisi keenam. Jakarta: PT Elex Media Komputindo.

Siagian, Sondang P. (2007).Manajemen Sumber Daya Manusia , Edisi Pertama, Cetakan Keempat Belas. Jakarta: Penerbit Bumi Aksara.

Steers, Richard M. (1985). Efektivitas Organisasi,Cetakan Kedua. Jakarta: Erlangga.

Sukmadinata, Nana Syaodih. (2010). Met ode Penelitian Pendidikan. 
Bandung: Remaja Rosda Karya.

Sabaruddin, Abdul. (2015). Manajemen

Kolaborasi Dalam Pelayanan

Publik Teori, Konsep dan Aplikasi.

Yogyakarta: Graha Ilmu.

Sugiyono. (2016). Metode Penelitian

Pendidikan Pendekatan Kuantitatif

Kualitatif dan R\&D. Bandung:

Alfabeta.

Wahab, Solichin Abdul. (2010). Analisis

Kebijaksanaan Dari Formulasi Ke

Implementasi Kebijaksanaan

Negara. Jakarta: PT Bumi Aksara. 